\title{
CRIPA: The Failure of Federal Intervention for Mentally Retarded People
}

\author{
John Kip Cornwell
}

The 1970's ushered in a new era in the care of retarded people in the United States. State-run institutions, long thought to be the most appropriate treatment facilities, were challenged by the federal government and private organizations for constitutional violations of patients' rights to an adequate standard of living. ${ }^{1}$

Wyatt $v$. Stickney ${ }^{2}$ was the first in a series of lawsuits aimed at securing the constitutional rights of institutionalized retarded people. It also marked the entry of the federal government into institutional litigation. The court requested the Attorney General to appear as amicus curiae ${ }^{3}$ to help gather information, evaluate treatment programs, and assist state officials in "meeting Federal standards for adequate care." Over the next few years, the Justice Department continued to assist plaintiffs in institutional suits either as litigating amicus ${ }^{\boldsymbol{b}}$ or plaintiff-intervenor. ${ }^{\boldsymbol{6}}$

In 1976, the federal government sought to broaden its involvement in institutional litigation by initiating lawsuits. ${ }^{7}$ The courts, however, dismissed the complaints, ruling that the Attorney General lacked statutory

1. See, e.g., Wyatt v. Stickney, 325 F. Supp. 781 (M.D. Ala. 1971), 334 F. Supp. 1341 (M.D. Ala. 1971), 344 F. Supp. 387 (M.D. Ala. 1972), affd sub nom. Wyatt v. Aderholt, 503 F.2d 1305 (5th Cir. 1974); New York State Ass'n for Retarded Children v. Rockefeller, 357 F. Supp. 752 (E.D.N.Y. 1973); Halderman v. Pennhurst State School \& Hosp., 446 F. Supp. 1295 (E.D. Pa. 1977).

2. In Wyatt, plaintiffs asked for a preliminary injunction against three state hospitals for the mentally handicapped, alleging inadequate care and treatment of patients confined there. $325 \mathrm{~F}$. Supp. at 782; 334 F. Supp. at 1342 n.1. The court agreed that conditions at the institution deprived patients of their constitutional right to treatment, and ordered state officials to promulgate and implement within six months a treatment program to upgrade the unconstitutional standard of care. $325 \mathrm{~F}$. Supp. at 784-86.

3. 325 F. Supp. at 786 .

4. S. Rep. No. 416, 96th Cong., 2d Sess. 3, reprinted in 1980 U.S. Code Cong. \& Admin. NEws 787, 791.

5. See, e.g., New York State Ass'n for Retarded Children v. Carey, 393 F. Supp. 715 (E.D.N.Y. 1975); Morales v. Turman, 383 F. Supp. 53 (E.D. Tex. 1974).

6. See, e.g., Gary W. v. Stewart, No. 74-2412 (E.D. La. filed July 26, 1976); Gates v. Collier, 349 F. Supp. 881, 885 (N.D. Miss. 1972); Battle v. Anderson, 376 F. Supp. 402, 407 (E.D. Okla. 1974).

7. See United States v. Solomon, 419 F. Supp. 358 (D. Md. 1976), affd, 563 F.2d 1121 (4th Gir. 1977); United States v. Mattson, No. 74-138-BU (D. Mont. Sept. 29, 1976), affd, 600 F.2d 1295 (9th Cir. 1979). 
authority to initiate these suits. ${ }^{8}$ Recognizing the need for federal participation, ${ }^{9}$ Congress responded to these dismissals by passing the Civil Rights of Institutionalized Persons Act (CRIPA) in $1980,{ }^{10}$ which gave the Attorney General power to initiate actions to protect mentally handicapped residents in state facilities. ${ }^{11}$

In the eight years since its passage, CRIPA has not fulfilled Congress' expectations. This Note describes the failure of federal intervention under CRIPA and proposes changes in the Act to enhance its efficacy. Section I analyzes the remedial processes of conciliation and litigation provided for in CRIPA and outlines the constitutional rights of institutionalized retarded people. Section II discusses the record of federal intervention thus far, focusing on the Justice Department's failure to act quickly when constitutional violations have been uncovered and on the shortcomings of negotiated remedies. This Section also examines the difficulties faced by third parties seeking to intervene in a CRIPA suit on behalf of the plaintiffs. Section III proposes changes in the Act necessary to eliminate the problems encountered since CRIPA's ratification. The proposed amendments aim to ensure expeditious action to correct CRIPA violations, broaden the participation of third parties in the settlement process, and expand the scope of monitoring in remedial decrees.

\section{Givil Rights of Institutionalized Persons Act (CRIPA)}

\section{A. Remedial Processes}

CRIPA authorizes the Attorney General to sue any state when he has reason to believe that it is engaged in a "pattern or practice"12 which

8. Solomon, 563 F.2d at 1124-26; Mattson, 600 F.2d at 1297.

9. The resources of the federal government allow it to pursue nationwide institutional reform more easily than can private citizens, legal services, and independent advocacy groups, who would shoulder such responsibility if the federal government were not involved. The Attorney General can also rely on other agencies, such as the Federal Bureau of Investigation and the Department of Health and Human Services, to assist the Justice Department in conducting investigations of retardation facilities and preparing a case for trial. S. REP. No. 416, supra note 4 , at 804 .

These other groups, by contrast, lack the money and manpower necessary to proceed on a broad scale. The Legal Services Corporation, for example, does not have enough funding even to provide adequate representation to those living below the poverty level. The Mental Health Law Project, the principal advocacy group of its kind in the country, employs only six full-time attorneys. Id. at 803 . These shortages, combined with the difficulties of communicating with mentally handicapped people, commuting long distances to meet with clients, and bringing an action of such magnitude, severely restrict the ability of such groups, acting alone, to protect retarded individuals. Id. at 802-03.

10. Pub. L. No. 96-247, 94 Stat. 349 (1980) amended by Pub. L. No. 97-256 (codified at 42 U.S.C. $\$ 1997$ (1982)). For a summary of events leading up to the passage of CRIPA, see Dinerstein, The Absence of Justice, 63 NEB. L. REv. 680, 683-92 (1984).

11. While CRIPA pertains to all state-run residential facilities, including prisons and institutions for mentally handicapped people, this Note focuses on actions taken at facilities for mentally retarded people.

12. 42 U.S.C. $\$ 1997 \mathrm{a}(\mathrm{a})$. The "pattern or practice" requirement was designed to limit causes of action to those situations where "unconstitutional or illegal practices are widespread, pervasive, and systematic, and adversely affect significant numbers of institutionalized individuals." S. REP. No. 416, supra note 4 , at 811 . Isolated acts or injuries are thereby excluded. 
subjects residents of public institutions to "egregious or flagrant" violations $^{13}$ which contravene their federal statutory and constitutional rights. ${ }^{14}$ Before bringing any such suit, the Attorney General must first conduct an investigation ${ }^{15}$ of the facility in question and inform the appropriate state government of its results. ${ }^{16}$ In addition, the state must be notified at least forty-nine days before suit is filed ${ }^{17}$ to allow adequate time for consultation and possible resolution of problems ${ }^{18}$ without the need for further legal action. ${ }^{18}$

The language and legislative history of the statute indicate that litigation is appropriate in the absence of a negotiated result. ${ }^{20}$ Faced with the possibility of costly litigation, a state may increase its efforts to negotiate a settlement. ${ }^{21}$ Thus, the threat of litigation is as much a weapon as the litigation itself.

\section{B. Youngberg v. Romeo}

CRIPA provides a framework for the protection of constitutional rights but does not specify the rights it is designed to vindicate. ${ }^{22}$ In Youngberg $v$. Romeo ${ }^{23}$ the Supreme Court's only pronouncement on the constitutional rights of institutionalized retarded people, the Court unanimously recognized the following liberty interests protected by the due process

13. 42 U.S.C. $\$ 1997 \mathrm{a}(\mathrm{a})$. Such violations are defined as "conditions which are willful or wanton or conditions of gross neglect." S. REP. No. 416, supra note 4 , at 811 .

14. 42 U.S.C. $\S 1997 \mathrm{a}(\mathrm{a})$.

15. 42 U.S.C. $\S 1997 \mathrm{~b}(\mathrm{a})$ (2). In deciding which institutions to investigate, the Justice Department conducts a preliminary review of all complaints received and looks further into " $[t]$ hose which on their face appear to describe legitimate or serious concerns . . . to determine whether formal investigation is required." Staff of Senate Subcomm. on the Handicapped, 99th Cong., 1st Sess., Report ON THE INSTITUTIONALized MENTAlly Disabled 151 (1985) [hereinafter STAFF REPORT]

16. Such notification must include the legal bases of the government's claims and the facts underlying them, as well as the "minimum measures" necessary to correct the infractions. 42 U.S.C. $\S$ $1997 \mathrm{~b}(\mathrm{a})(1)(\mathrm{A})-(\mathrm{C})$.

17. 42 U.S.C. $1997 \mathrm{~b}(\mathrm{a})(1)$.

18. Of course, the Attorney General may notify a state more than 49 days before filing suit. Section 1997b(a)(2)(C) specifies that the Attorney General should be satisfied, before filing suit, that state officials have had "reasonable time" to take remedial action in light of the scope of redress requested and the urgency of the need for improvement.

19. Permitting the state to remedy conditions benefits the government by saving time and money it would otherwise spend on litigation. In addition, the remedy proposed will be more easily enforced if the state itself has fashioned it; a state-sponsored remedy will meet with less resistance from the officials implementing it. Thus, it is not surprising that Congress preferred voluntary, state-sponsored remedies wherever possible. See H.R. CoNF. REP. No. 897, 96th Cong., 2d Sess. 13, reprinted in 1980 U.S. Code Cong. \& Admin. News 832, 837; S. Rep. No. 416, supra note 4, at 814.

20. See 42 U.S.C. $\$ 1997$ a(a). The Senate Report refers to litigation as the "single most effective method for redressing the systematic deprivations of institutionalized persons' constitutional and Federal statutory rights." S. REP. No. 416, supra note 4, at 809 . CRIPA is accordingly designed to give the Attorney General the power to address institutional abuse "in a systematic fashion, engaging in a program of selective litigation against those institutions where the most egregious constitutional deprivations affect the largest number of people." Id. at 799 (emphasis added).

21. See Dinerstein, supra note 10 , at 706 .

22. See Note, The Constitutional Right to Treatment in Light of Youngberg v. Romeo, 72 Geo. L.J. $1785,1802 \& \mathrm{n} .96$ (1984).

23. 457 U.S. 307 (1982). 
clause of the Fourteenth Amendment: the right to reasonable care and safety, ${ }^{24}$ freedom from bodily restraint, ${ }^{25}$ adequate food, shelter, clothing, and medical care, ${ }^{26}$ and adequate training and habilitation to ensure safety and freedom from bodily restraint. ${ }^{27}$ In determining whether an institution is operating in accordance with these standards, the Court held that "decisions made by the appropriate professional [at the institution] are entitled to a presumption of correctness." 28 Thus, the federal government may intervene only when it has reason to question this presumption. In such a case, CRIPA authorizes the government to send a team of legal and medical experts into retardation facilities to determine whether there are any Romeo violations. ${ }^{29}$

\section{The Failure of Federal Intervention}

\section{A. The Failure To Act}

GRIPA capitalized on the benefits of federal intervention while it preserved the state's ability to negotiate remedies. Relying solely on the process of conciliation with state authorities, however, the federal government did not file a single suit involving an institution for retarded people during the first years of the Act's existence. ${ }^{30}$ Dissatisfaction with the Justice Department's apparent failure to protect the rights of retarded citizens resulted in congressional hearings, held in November $1983^{31}$ and April $1985,{ }^{32}$ to look into the Justice Department's efforts under CRIPA. William Bradford Reynolds, Assistant Attorney General in charge of Civil Rights, defended the Justice Department's record at these hearings. While he admitted that no suits had been brought, Reynolds emphasized the progress made through negotiation with state officials to remedy violations at

24. Id. at $319,322,324$.

25. Id.

26. Id. at 324 .

27. Id. at 319 n. $25,322,324$.

28. Id. at 324 .

29. See 42 U.S.C. $\$ 1997$ b(a). Some commentators have criticized the Justice Department for refusing to vindicate certain rights-e.g., the right to treatment in the least restrictive environment-not developed by the Court in Romeo. See Note, supra note 22, at 1801-08; Dinerstein, supra note 10, at 694-702; Cook, The Substantive Due Process Rights of Mentally Disabled Clients, 7 Mental Disability L. ReP. 346 (July/August 1983), reprinted in Enforcement of Section 504 of the Rehabilitation Act: Institutional Care and Services for Retarded People: Hearing before the Subcomm. on the Handicapped of the Senate Comm. on Labor and Human Resources, 98th Cong., 1st Sess. 174-85 (1983) [hereinafter 1983 Hearing]. This Note, however, does not take issue with the government's policy in this regard, nor does it criticize the Justice Department's reliance on a literal interpretation of Romeo.

30. In fact, the first suit was not filed until 1986 in the case of United States v. New Mexico, No. 86-09-32M (D.N.M. filed Aug. 8, 1986) [hereinafter Fort Stanton].

31. See 1983 Hearing, supra note 29.

32. Examining the Issues Related to the Care and Treatment of the Nation's Institutionalized Mentally Disabled Persons: Joint Hearings Before the Subcomm. on the Handicapped of the Senate Comm. on Labor and Human Resources and the Subcomm. on Labor, Health and Human Services, Education and Related Agencies of the Comm. on Appropriations, 99th Cong., 1st Sess. (1985). 
investigated facilities. ${ }^{33}$ Lawsuits, he argued, should be initiated only as a last resort. ${ }^{34}$

\section{Avoiding Litigation}

By providing a reasonable opportunity for conciliation, ${ }^{35}$ Congress did not intend to give the state unlimited time to negotiate a settlement. ${ }^{36}$ On several occasions, however, the Justice Department has avoided bringing suit, choosing instead to negotiate with the state for as long as is necessary to reach an agreement. ${ }^{37}$ Throughout this waiting period, "[unconstitutional] conditions .... fester, destroying the purpose of federally mandated intervention." 38

Assistant Attorney General Reynolds offered two explanations for the Justice Department's reluctance to litigate: the desire to minimize conflict between the state and federal governments ${ }^{39}$ and concern that litigation is time consuming. ${ }^{40}$ While minimizing discord is a legitimate objective, it must nevertheless remain secondary to the fundamental purpose of these negotiations: the elimination of unconstitutional conditions. The framers of the Act intended no less in emphasizing the need for litigation where conciliation produces no results within a "reasonable time."41

The claim that litigation should be avoided because it may unnecessarily prolong unconstitutional conditions seems misguided for two reasons. First, when CRIPA was originally passed, one justification offered for extending the federal government's authority was the positive effect its presence would have on the speed of litigation..$^{42}$ It is thus inappropriate to refuse to litigate because the process might be lengthy; to justify such refusal, the Justice Department needs concrete proof of the protracted nature of CRIPA litigation. Secondly, the conciliation policy favored by the

33. 1983 Hearing, supra note 29, at 16 (prepared statement of Wm. Bradford Reynolds).

34. Id. at 17.

35. See supra notes 15-19 and accompanying text.

36. The legislative history specifies, in fact, that the Attorney General need not "wait months or years between the initial notification of commencement of an investigation and the filing of suit." $S$. REP. No. 416, supra note 4, at 815; see also Dinerstein, supra note 10, at 706 (emphasizing conciliation to the exclusion of litigation "turns history on its head").

37. See infra text accompanying notes 43-55.

38. STAFF REPORT, supra note 15 , at 6.

39. Litigation is avoided at all costs in the interest of achieving an "absolute minimum of StateFederal legal confrontation." 1983 Hearing, supra note 29, at 5 (testimony of Wm. Bradford Reynolds).

40. Litigation only "bog[s] the Government down," id. at 5 (testimony of Wm. Bradford Reynolds), and forces institutionalized residents to wait years "for court battles to unfold before real relief comes ..." Id. at 16 (prepared statement of Wm. Bradford Reynolds).

41. See supra note 18.

42. The Justice Department's expertise would ensure a high standard of representation for the plaintiff class and could result in a notable conservation of judicial resources. The preparation of a "tightly structured" case could accelerate the pace of litigation and/or settlement, "thus saving weeks or months of discovery and trial." S. REP. No. 416, supra note 4, at 805. 
Justice Department does not indicate that such conciliation is a "speedy" alternative to litigation.

\section{The Problems of Conciliation}

The government's failure to litigate would not frustrate CRIPA's purpose if its program of conciliation produced quick and effective remedies. Negotiations, however, have continued for years before realizing any concrete results. For example, at Oregon's Fairview Training Center, the state Attorney General refused a Justice Department request for access to the institution to conduct on-site inspections in mid-1983. The federal government did not seek injunctive relief, however, until July $28,1986,{ }^{43}$ three years after the initial inquiry into conditions at the facility. Similar delays have occurred in other cases. In the case involving the Wheat Ridge Regional Center in Colorado, ${ }^{44}$ the government notified the state of unconstitutional conditions in December 1984. It was not until July 1986, however, that the state and federal governments incorporated their agreement into a consent decree. ${ }^{45}$ Residents of the Belle Ghase State School in Louisiana suffered a similar time lag. The Attorney General informed the Governor of "egregious and flagrant conditions" at the school in January 1986; the consent decree was not finalized until July $1987 . .^{46}$

The Fairview and, to a lesser extent, Wheat Ridge and Belle Chase scenarios are the types of situations CRIPA was designed to eliminate. Giving broad powers to the Justice Department was thought to be an effective way of challenging intransigence at the state level, albeit in as cooperative a manner as possible. Instead, the government has acted on its authority by waiting for states to remedy the problems.

The Rosewood Center in Owing Mills, Maryland ${ }^{47}$ presents perhaps the most powerful example of the problems which have resulted from the government's reliance on conciliation. A Senate investigatory team found

43. United States v. Oregon, No. 86-961 LE (D. Or. filed July 28, 1986) [hereinafter Fairview].

44. United States v. Colorado, No. 86-F-1470 (D. Colo. filed July 10, 1986) [hereinafter Wheat Ridge].

45. Consent decrees have been widely used in institutional reform litigation to avoid lengthy discovery and to involve the defendant in the remedial process. See Note, The Modification of Consent Decrees in Institutional Reform Litigation, 99 HARv. L. REv. 1020 (1986) [hereinafter Note, Modification of Consent Decrees]; Schwarzchild, Public Law by Private Bargain: Title VII Consent Decrees and the Fairness of Negotiated Institutional Reform, 1984 Duke L.J. 887, 898-901. For additional background on consent decrees, see Anderson, The Approval and Interpretation of Consent Decrees in Civil Rights Class Action Litigation, 1983 U. ILL. L. REv. 579; James, Consent Judgments as Collateral Estoppel, 108 U. PA. L. Rev. 173 (1959); Comment, Consent Decrees and the Judicial Function, 20 CATH. U.L. REv. 312 (1970); Note, The Consent Judgment as an Instrument of Compromise and Settlement, 72 HARv. L. REv. 1314 (1959). For a thorough analysis of the consent decree negotiated in New York State Ass'n for Retarded Children $v$. Rockefeller, see D. Rothman \& S. Rothman, The Willowbrook Wars 127-253 (R. Mnookin ed. 1984).

46. See Consent Decree, United States v. Louisiana, No. 87-025, at 2, § 8. (E.D. La. July 23, 1987) [hereinafter Belle Chase].

47. See United States v. Maryland, No. M-85-227 (D. Md. filed Jan. 17, 1985) [hereinafter Rosewood]. 
that "[t]he time lag between the finding of unconstitutional conditions at Rosewood and the settlement . . . shows, at the very least, that the [Justice] Department's conciliatory approach . . . has the potential to negate the type of federal involvement ... envisioned and mandated in CRIPA." 48 So averse was the government to confrontation with the state that it allowed life-threatening conditions to linger for years at the institution. The "forty-nine-day" letter to Governor Hughes indicated the gravity of the alleged violations, which included the following: the rape of six severely handicapped residents by an intruder, the sexual abuse of a male resident by an employee, "nonconsensual sexual contact" between one resident and "at least one and possibly three" others, and two deaths-one by drowning when the resident was left unattended in the bathtub and another by exposure to the cold when a resident "managed to . . . escape from Rosewood." 9 The government's letter, however, did not require Rosewood to eliminate the conditions that gave rise to these events; ${ }^{50}$ it asked only that the state reduce the level of abuse and neglect, encourage staff members to report instances of abuse to institutional authorities, and decrease the incidence of resident-to-resident abuse..$^{51}$ The attitude engendered by these instructions is antithetical both to the Justice Department's duty to advocate in the best interests of the class members it represents and to the requirement in GRIPA that the "forty-nine-day" letter specify "the minimum measures [necessary to] remedy the alleged conditions and the alleged pattern or practice of resistance."

The delays apparent in Rosewood and other cases contrast with the government's more expeditious action on other occasions. In its action against the Southbury Training School in Connecticut, ${ }^{83}$ less than one year passed between the issuance of the "forty-nine-day letter" to Governor O'Neill and the negotiation of a remedial decree. Similarly, the government filed suit only seven months after notifying the governor of New Mexico of conditions at the Fort Stanton Hospital and Training School. ${ }^{54}$ The Justice Department felt that New Mexican officials had had a reasonable amount of time to correct the violations and had failed to do so. ${ }^{\mathrm{s5}}$

48. STAFF REPORT, supra note 15 , at 169.

49. 1983 Hearing, supra note 29 , at 66 (letter from Wm. Bradford Reynolds to Maryland Governor Hughes dated Feb. 10, 1982).

50. Such a mandate is necessary to fulfill CRIPA's underlying purpose which is to "ensure that institutionalized citizens will be afforded the full measure of protections guaranteed them by the Constitution of the United States." S. ReP. No. 416, supra note 4 , at 790 (emphasis added).

51. 1983 Hearing, supra note 29, at 70 (letter from Wm. Bradford Reynolds to Maryland Governor Hughes dated Feb. 10, 1982).

52. 42 U.S.C. $\S 1997 \mathrm{~b}(\mathrm{a})(1)(\mathrm{C})$ (1982) (emphasis added).

53. United States v. Connecticut, No. N-86-252 (D. Conn. filed July 25, 1986) (hereinafter Southbury].

54. See Fort Stanton, supra note 30.

55. The state had rejected a formal settlement proposal and refused otherwise to remedy the Romeo violations-e.g., failure to provide adequate medical care, unreasonable use of bodily restraints-alleged by the government. Memorandum from Wm. Bradford Reynolds to Attorney Gen- 
If the Justice Department can move as quickly as it did in Southbury and Fort Stanton, residents at other institutions are entitled to action which is equally expeditious.

\section{B. The Failure of Acting}

The failure of the government to act in a timely fashion represents only half of the problem. There are also some serious doubts about the benefit to retarded citizens of specific measures taken by the federal government. The consent decrees it has negotiated may appear, at first blush, to remedy alleged violations, but the failure to provide for effective enforcement both within and outside of the institution substantially undermines their utility.

\section{Inadequate Decrees}

This problem is best illustrated by the treatment of two issues in consent decrees: community placement and monitoring. The Supreme Court ${ }^{\mathrm{sB}}$ has not found a constitutional right to community placement ${ }^{57}$ or even placement in the "least restrictive environment;" thus, the state is not required to depopulate its institutions nor is the government required to press for community placement quotas. However, in fulfillment of its advocacy responsibilities, the federal government must ensure that if residents are placed out of the institution, they are placed in facilities whose care and treatment conforms to constitutional standards.

The decrees do not satisfy this burden. They make community placement an optional means of meeting resident/staff ratios ${ }^{88}$ and leave the selection of residents, where specified, to "professional staff" at the institution. ${ }^{59}$ This scheme is dangerous in that it allows residents to be relocated in facilities which may provide substandard, unconstitutional care because they are not governed by the terms of the consent decree. ${ }^{60}$

As it now stands, Southbury, Wheat Ridge, Belle Chase and Rosewood are free to place their residents anywhere they choose. The federal gov-

eral Meese (July 25, 1986) (discussing Fort Stanton).

56. In Youngberg v. Romeo, 457 U.S. 307 (1982), the Court did not reach the issue of community placement or placement in the "least restrictive environment." Since the Justice Department relies on a literal reading of Romeo to structure its advocacy, it has not felt compelled to vindicate a right to placement outside of the institution.

57. The Second Circuit explicity rejected a right to community placement in Society of Goodwill to Retarded Children v. Cuomo, 737 F.2d 1239, 1247 49 (2d Cir. 1984).

58. Consent Decree, Southbury, supra note 53, at 9, \$ IV(3); Consent Decree, Wheat Ridge, supra note 44, at 5, §IV(1); Consent Decree, Belle Chase, supra note 46, at 8, § IV(3); Consent Decree, Rosewood, supra note 47 , at 5 , § IV(1).

59. Consent Decree, Southbury, supra note 53, at 9, § IV(3); Consent Decree, Belle Chase, supra note 46, at 8, § IV(3); Consent Decree, Rosewood, supra note 47, at 5, § IV(1).

60. The monitoring of community placements is "critical in order to prevent the problems of abuse and neglect . . . from following mentally retarded people from the institution into the community." STAFF RePORT, supra note 15, at 195. 
ernment has failed to specify what constitutes acceptable placement. After stating that community placement was an acceptable, albeit voluntary, means of meeting staffing quotas, the federal government, as counsel for the plaintiff class, should have moved under CRIPA to protect the class' interests by promulgating standards in the event the state chose to use the community placement option. ${ }^{\text {BI }}$

The government is aware of the need for guidelines. In CARC v. Thorne, ${ }^{62}$ a privately initiated suit involving Connecticut's Mansfield Training School in which the government participated as amicus curiae, an entire portion of the decree $e^{63}$ is devoted to outlining the standards for community placement. ${ }^{64}$ In addition to promulgating standards for choosing community facilities, the Mansfield decree provides for the development of a "quality assurance system" to monitor residences' compliance with constitutional and statutory requirements. ${ }^{65}$ The Southbury, Wheat Ridge, Belle Chase, and Rosewood decrees contain no such provision. Thus, even if the state, through its own initiative, were meticulous in choosing facilities which offered the highest standard of care, there would be no guarantee that residents placed there would receive such high quality services indefinitely.

The absence of provisions relating to the monitoring of placements is part of a bigger problem. The decrees fail to provide for any independent monitoring body to ensure compliance, ${ }^{66}$ instead, they leave these respon-

61. The government's duty was all the more imperative in Southbury, where during negotiations the state made clear its intention to deinstitutionalize residents. Interview with Dr. Robert Griffith, former Director of Southbury Training School (March 1987) [hereinafter Griffith interview]; see also Memorandum in Support of Motion to Intervene of CARC et al. at 6, Southbury, supra note 53. This intention was finalized in the state's proposed consent decree implementation plan which provides for the relocation of approximately 400 residents during the first four years that the plan is in effect. Proposed Consent Decree Implementation Plan at 62, Southbury, supra note 53.

62. No. H-78-653 (D. Conn. Nov. 7, 1983).

63. As non-litigating amicus, the Justice Department did not participate in decree negotiations.

64. Some of these standards are stated in general terms: Placements must "assure the safety, health, and well-being" of each resident and permit "reasonable access to . . . surrounding communities, geographically and socially." Consent Decree, CARC v. Thorne, at $6, \S$ IV(B)(1)-(2). Others are more specific: Placements must approximate "home-like" settings of no more than eight beds "unless special circumstances exist," as defined therein. Id. at $6, \S$ IV(B)(3).

65. The decree specilies that the system must accomplish at least the following: (1) ensure that individual class members live, work, learn, and recreate in a humane physical and psychological environment that affords the opportunity to interact with and participate in the community; (2) ensure that class members are protected from harm; (3) review and monitor individual habilitation plans to ensure that such plans are developed and are in fact implemented; (4) ensure that case managers and providers have such training as is necessary to effectively and professionally discharge their responsibilities under this order; (5) determine through an analysis of individual program data whether class members are progressing or regressing in programs and services developed through this order; and (6) periodically publish a report which shall be available to the public that discusses and analyzes the data collected under (1) through (5). Id. at 7-8, § IV(E)(1)-(6).

66. In Southbury, supra note 53, negotiators for the state were willing to have representatives from other groups with interest in the suit-e.g., the Connecticut Association of Retarded Citizens and the Connecticut Office of Protection and Advocacy for Handicapped and Developmentally Disabled Persons-participate in the enforcement of the decree. The Justice Department, however, was not amenable to this suggestion. Griffith interview, supra note 61 . 
sibilities to the federal government. ${ }^{67}$ Given the breadth of the decrees, the government would need to be in the hospital, school, and each residential "cottage" more often than not to ensure effective compliance. In reality, however, monitors tend to visit the institutions infrequently. ${ }^{68}$ For monitoring to succeed, there needs to be an increased presence both on the grounds of the institution and in any satellite facilities used to house residents.

\section{The Inability To Intervene}

In an effort to change controversial provisions in consent decrees, private advocacy groups have unsuccessfully tried to intervene in pending suits. ${ }^{69}$ For example, in Southbury, three organizations tried to intervene after the consent decree was submitted to the federal district court for approval. The Home and School Association (H\&S), ${ }^{70}$ CARG, and Protection and Advocacy $(\mathrm{P} \& \mathrm{~A})^{71}$ all filed motions based on Rule 24 of the Federal Rules of Civil Procedure, which delineates standards for "intervention of right" and "permissive intervention" in actions pending before the court. All three motions were denied. ${ }^{72}$

67. The Southbury decree allows the federal government and its enforcement personnel "reasonable access to the facilities, records, residents, and employees of the Southbury Training School upon reasonable notice to the State for the purpose of ascertaining compliance with the Decree. Such access shall continue until this Consent Decree is terminated." Consent Decree, Southbury, supra note 53, at $15, \S \mathrm{VI}(3)$. The Belle Chase decree contains identical wording. See Consent Decree, Belle Chase, supra note 46 , at $13, \S \mathrm{VI}(3)$. Wheat Ridge is less specific; it states merely that compliance "will be monitored by the United States consistent with the Consent Decree . . . and with the principles set forth in . . . this Agreement." Consent Decree, Wheat Ridge, supra note 44, at 8, § V. Rosewood is similarly vague, focusing on the government's access to information and the receipt of compliance reports from state officials. Rosewood, supra note 47 , at 15 , $\S$ VII(3)-(5).

68. Federal monitors, for example, have visited the Southbury Training School to review medical practices only three times since the decree went into effect in July 1986. Interview with Dr. Jean Gino, Medical Director of the Southbury Training School (Apr. 1988).

69. See Schwarzchild, supra note 45, at 914-23 \& nn.166-67 (listing cases in which intervention was denied); Note, Modification of Consent Decrees, supra note 45, at 1036-37 (noting reluctance of courts to allow intervention before decree is entered); Note, Institutional Reform Litigation: Representation in the Remedial Process, 91 YALE L.J. 1474, 1480-81 (1982).

70. The Home and School Association is composed of parents of residents at the Southbury Training School.

71. Protection and Advocacy's full title is "Office of Protection and Advocacy for Handicapped and Developmentally Disabled Persons." The Office was established by the Connecticut General Assembly pursuant to the Developmental Disabilities Assistance and Bill of Rights Act, 42 U.S.C. $\S \S$ 6000-6002, 6012, 6021-6030, 6033, 6041-6064, 6081-6083 (1984). That Act is designed to help individual states create systems "to protect the legal and human rights of persons with developmental disabilities." 42 U.S.C. $\$ 6000$ (b)(2)(E) (Supp. II 1984); see CoNN. GEN. STAT. \$§ 461-467; 42 U.S.C. \$ 6012 and regulations thereunder.

As an organization formed by congressional mandate to advocate for mentally handicapped citizens, Protection \& Advocacy is in an arguably stronger position than other proposed intervenors. It seems contrary to congressional intent for courts to deny Protection \& Advocacy access to GRIPA suits since such participation would allow the Office to do exactly what it was intended to do: vindicate the rights of mentally handicapped people.

72. See United States v. Connecticut, No. N-86-252 (D. Conn. Dec. 22, 1986) (order denying intervention in pending action). The court had already denied P\&A's right to intervene in the settlement negotiations between the state and federal governments. P\&A had argued that the Justice Department had a duty under CRIPA to consult with it during negotiations, but the court rejected this 
To succeed in obtaining intervention of right, a petitioner must show an "interest" in the action which may be adversely affected by the outcome of the case and that the existing parties would not safeguard that interest. ${ }^{73}$ The court did not dispute petitioners' interest in the case. It rejected, however, the claims of H\&S and CARG that the decree's community placement provisions jeopardized that interest in any way, for there was no indication in the decree's proposed implementation plan that either organization would be unable to take part in decisions regarding the relocation of residents. ${ }^{74}$ In fact, the proposed plan expressly provides for the input of parents and advocates in the placement decision. ${ }^{75}$

However noteworthy, these promises of participation do not negate language in the decree which ultimately invests full authority for making placement decisions in the institution's professional staff. ${ }^{76}$ The Mansfield decree, by contrast, recognized the primacy of parental input into the placement decision. It required defendants to "give substantial weight to the views of class members, as well as their parents or guardian, or closest relative, who are actually involved, in the placement process." 77 The absence of similar wording in the Southbury decree, together with the lack of standards for community placement and subsequent quality assurance, ${ }^{78}$ jeopardizes significantly petitioners' interest in this action.

Having demonstrated this potentially adverse effect on their interest, petitioners were then required to demonstrate that the government's representation was or may have been inadequate. ${ }^{79}$ Evidence of the danger

reading of the Act, holding that its statutory language "suggest[ed] that only officials with authority to bind the state need be involved in the negotiation process." Dober v. Meese, No. N-86-195(EBB), slip op. at 5 (D. Conn. Sept. 15, 1986).

In the only other attempted intervention in a CRIPA suit involving the mentally retarded, the district court denied the motion to intervene of five Fairview residents and all those similarly situated. See United States v. Oregon, 86-961 LE (D. Or. Feb. 3, 1987) (order denying intervention because of adequacy of government's representation and potential prejudice or delay such intervention might cause). For a discussion of attempted intervention in the context of a CRIPA suit involving the mentally ill, see United States v. Massachusetts (D. Mass. Apr. 28, 1986) (order finding intervention impermissible in any CRIPA suit).

73. Rule 24(a)(2) states that intervention as of right shall be granted

when the applicant claims an interest relating to the property or transaction which is the subject of the action and he is so situated that the disposition of the action may as a practical matter impair or impede his ability to protect that interest, unless the applicant's interest is adequately represented by existing parties (emphasis added).

FED. R. Civ. P. 24(a).

74. United States v. Connecticut, No. N-86-252 (D. Conn. Dec. 22, 1986) (order denying intervention in pending action).

75. Id. (citing Proposed Consent Decree Implementation Plan at 62).

76. See supra text accompanying note 59.

77. See Consent Decree, CARC v. Thorne, No. H-78-653 (D. Conn. Nov. 7, 1983), at 4, § II(F)

78. See supra text accompanying notes 61-65.

79. See Trbovich v. United Mine Workers, 404 U.S. 528, 538 n.10 (1972) (noting that Rule $24(a)(2)$ requires only that proposed intervenors show that representation of their interests "may be" inadequate and that the showing required "should be ... minimal"); see also Shapiro, Some Thoughts on Intervention Before Courts, Agencies, and Arbitrators, 81 HaRv. L. Rev. 721, 741 (1968) (issue of adequacy is always central to disposition of motion to intervene as of right). But see Note, Intervention in Government Enforcement Actions, 89 HARv. L. REv. 1174, 1186 (1976) (once 
posed to the plaintiff class by the proposed decree ${ }^{80}$ satisfies this burden..$^{81}$ Thus, the court should have granted petitioners' intervention as of right. ${ }^{\mathbf{8 2}}$

Petitioners also argued, in the alternative, for a right of permissive intervention under Rule 24(b)(2). ${ }^{83}$ The court denied H\&S's motion for failure to present "a question of law or fact in common" with the principal action; ${ }^{84}$ it predicated the denial of relief to CARC and P\&A, on the other hand, on largely the same rationale as in the Rule 24(a) context: the adequacy of the government's representation and the ability to pursue additional claims in a separate action. ${ }^{85}$ This reasoning is not in keeping with the language of Rule 24(b), which emphasizes consideration of the potential "delay" or "prejudice" caused by the proposed intervention. ${ }^{\mathbf{8 B}}$ The court did not address these issues when discussing permissive intervention, but petitioners argue that no delay or prejudice will result from their participation. ${ }^{87}$

impairment of litigable interest is established, difficulty in finding adequate representation rarely bars intervention). See generally Note, Modification of Consent Decrees, supra note 45, at 1036-37 (government negotiated institutional reform decrees sometimes fail to protect third party interests adequately); Schwarzchild, supra note 45, at 914-23.

Some courts have held that the demonstration of inadequacy must be especially clear when it is the government that is challenged. See, e.g., Apache County v. United States, 256 F. Supp. 903 (D.D.C. 1966); United States v. ASCAP, 11 F.R.D. 511 (S.D.N.Y. 1951). Others have rejected this limitation. See, e.g., Ford Motor Co. v. Bisanz Bros., 249 F.2d 22, 28 (8th Cir. 1957); Atlantic Ref. Co. v. Standard Oil, 304 F.2d 387 (D.C. Cir. 1962); International Mortgage \& Inv. Corp. v. Von Clemm, 301 F.2d 857 (2d Cir. 1962).

80. See supra text accompanying notes 56-68.

81. The court imposed a heavier burden that required petitioners to overcome a presumption of adequate representation by "demonstrat[ing] that the government did not fairly and vigorously represent the public interest in negotiating the decree." Given the gravity of the decree's flaws, the court was arguably incorrect in denying petitioners' motions in accordance with this standard.

82. Both H\&S and CARC satisfied the test used by the First and Ninth Circuits to determine whether existing parties adequately represented the intervenors' interests. They showed that their interests were sufficiently divergent from those of the government that the latter was not likely to argue their claim(s) and that their presence was therefore likely to "add some necessary element to the proceedings which would not be covered by the parties in the suit." United Nuclear Corp. v. Cannon, 696 F.2d 141, 144 (1st Cir. 1982) (citing Blake v. Pallan, 554 F.2d 947, 954-55 (9th Cir. 1977)); see also People v. Tahoe Regional Planning Agency, 792 F.2d 775, 778 (9th Cir. 1986) (describing Ninth Circuit's test).

83. Rule $24(\mathrm{~b})(2)$ provides that such intervention will be permitted:

when an applicant's claim or defense and the main action have a question of law or fact in common. ... In exercising its discretion, the court shall consider whether the intervention will unduly delay or prejudice the adjudication of the rights of the original parties.

FED. R. Civ. P. 24(b).

84. United States v. Connecticut, No. N-86-252 (D. Conn. Dec. 22, 1986) (order denying intervention in pending action).

85. Id.

86. In this regard, Wright, Miller \& Kane have noted that:

it seems most useful to rely on the discretion of the court in allowing permissive intervention. If allowing the applicant to come into the case . . . will cause undue delay or prejudice to the existing parties, he should not be allowed to intervene. . . . If these untoward results will not occur, and allowing the would-be intervenor to come in and present his counterclaim would avoid multiplicity of litigation or otherwise be desirable, intervention should be granted for this purpose.

G. Wright, A. Miller \& M. Kane, Federal. Practice and Procedure: Civil 2d $\$ 1921$ (2d ed. 1986).

87. See, e.g., Memorandum in Support of Motion to Intervene of CARC et al. at 8-9, Southbury, 
Moreover, as a matter of policy, the court should have exercised its discretion to grant permissive intervention. It is fallacious to believe that there is one "correct" conception of the best interests of retarded people. ${ }^{88}$ Given the heterogeneity of interests and concerns, ${ }^{89}$ it behooves the judge to seek a diversity of perspectives before deciding what is in the best interest of the plaintiff class. ${ }^{30}$

\section{REMEDYING THE ACT}

Congress designed CRIPA to give the Justice Department the authority to initiate and vigorously pursue institutional reform. In general, however, the government has followed a course of conciliatory inaction which has produced, on several occasions, consent decrees which place the future well-being of retarded citizens in jeopardy. When private organizations have attempted to intervene on behalf the plaintiff class, they have been unable to overcome CRIPA's presumption in favor of the adequacy of the government's representation. ${ }^{91}$ While continuing to guarantee the federal government's power to initiate and pursue legal action against state institutions for the retarded, the Act needs to specify stricter guidelines to be followed in pursuit of such action.

\section{A. The Initiation of Lawsuits}

While the federal government has initiated actions by conducting institutional investigations, lengthy "conciliation" periods have attenuated further progress. ${ }^{92}$ CRIPA should be amended to require the Justice Department to bring suit ${ }^{93}$ after six months, ${ }^{94}$ if state officials fail to make

supra note 53 (arguing that while intervention may result in the consideration of certain additional issues, proper remediation requires the participation of all concerned).

88. The government's response may also be influenced by political pressures which may not work to the benefit of retarded citizens. Cf. Note, Modification of Consent Decrees, supra note 45, at 1034 (actions of defendant government may reflect its own concerns rather than the public interest).

89. Cf. Horowitz, Decreeing Organizational Change: Judicial Supervision of Public Institutions, 1983 DuKE L.J. 1265, 1291-92 (noting divergent interests of plaintiffs in institutional reform litigation); Wilton, Functional Interest Advocacy in Modern Complex Litigation, 60 WAsH. U.L.Q. 37 (1982).

90. See Shapiro, supra note 79, at 745-46, 748; Fiss, The Supreme Court, 1978 Term-Forward: The Forms of Justice, 93 Harv. L. Rev. 1, 21 (1979); cf. Missouri-Kansas Pipe Line Co. v. United States, 312 U.S. 502, 505 (1941) (rejecting argument that Rule 24(a) lists "a comprehensive inventory of the allowable instances for intervention" and holding that intervention on other grounds may be required in public interest).

91. See United States v. Connecticut, No. N-86-252 (D. Conn. Dec. 22, 1986) (order denying intervention which finds presumption of adequacy of government's representation in CRIPA suits); $c f$. United States v. American Cyanamid Co., 556 F. Supp. 357, 360 (S.D.N.Y. 1982), affd in part, rev'd in part, 719 F.2d 558 (2d Cir. 1983) (Rule 24(a) contains implied presumption of adequacy of government representation in context of antitrust consent decrees).

92. See supra text accompanying notes $43-55$.

93. Filing suit does not preclude continued negotiations. As the legislative history of CRIPA makes clear, one of the primary benefits of filing suit is acceleration of the process of negotiation and settlement. See supra text accompanying note 42.

94. Once suit is filed, it should be vigorously enforced. The Justice Department's conduct in the 
measurable progress within this period in redressing Romeo violations ${ }^{95}$ found at the institution. ${ }^{98}$ Six months seems an appropriate time period, ${ }^{97}$ given the government's recent action in Fort Stanton. ${ }^{88}$ Less than six months after notifying the Governor of New Mexico of the results of its investigation, the Justice Department filed suit, believing that state officials had had a reasonable period to correct the constitutionally offensive conditions. .98

At the conclusion of first six-month remedial period, another would begin during which the state would have to implement its proposed strategy. If it failed to do so, the Justice Department then would be required to initiate legal action. ${ }^{100}$ This proposal does not require the state to redress

two suits brought to date against institutions for the retarded does not indicate consistently vigorous enforcement. Fort Stanton, for example, remains in the discovery phase more than a year after suit was filed. This result may be explained in part by the change of administration in New Mexico. Telephone interview with Verlin Hughes, Staff Attorney, Special Litigation Division, Department of Justice (Oct. 1987),

In Fairview, conversely, the time period for discovery has been extended by a flurry of motions filed mostly by the state. The Justice Department has prevailed in most instances. United States v. Oregon, No. 86-961 LE (D. Or. Oct. 7, 1986) (order denying defendant's motion for a more definite statement); United States v. Oregon, No. 86-961 LE (D. Or. Jan. 26, 1987) (order upholding plaintiffs motion to compel discovery); United States v. Oregon, No. 86-961 LE (D. Or. Feb. 3, 1987) (order denying motion to intervene of five Fairview residents and those similarly situated); United States v. Oregon, No. 86-961 LE (D. Or. Apr. 7, 1987) (order denying defendant's motion for partial judgment on pleadings); United States v. Oregon, No. 86-961 LE (D. Or. April 7, 1987) (order upholding in part and rejecting in part defendant's motion to compel discovery); United States v. Oregon, No. 86-961 LE (D. Or. Oct. 2, 1987) (order denying defendant's counterclaim for declaratory and injunctive relief).

95. See supra text accompanying notes 23-27.

96. To meet this "measurable progress" standard, the state would need to submit a proposal outlining its strategy for redressing the alleged constitutional violations in staffing, programming, recordkeeping and other relevant areas. The state's proposal would in effect be an abbreviated, skeletal model of the consent decree implementation plan currently submitted after the decree is entered by the court. The Justice Department would decide if the proposal constituted a "good faith" effort to respond to the "49-day letter."

97. The six-month provision would not contravene any of the language currently contained in the Act; it would simply clarify $\$ 1997 \mathrm{~b}(\mathrm{a})(2)(\mathrm{C})$ which requires the Attorney General to ensure that state officials have had "reasonable time to take appropriate action to correct such conditions and pattern or practice."

98. Six months is too long to wait if the government's investigation uncovers a pattern of lifethreatening conditions or abuses at a facility. In such cases, the Justice Department should bring suit immediately. This brand of emergency relief has precedent in Wyatt, where, during negotiations, the district judge ordered immediate correction of fire safety violations which posed an imminent threat to the safety of residents at the facilities under investigation. Interview with Charles R. Halpern, Counsel for Plaintiffs in Wyatt $v$. Stickney (Nov. 1987).

99. Memorandum from Wm. Bradford Reynolds to Attorney General Meese (July 25, 1986) (on file with author). Fort Stanton is a small facility and is admittedly easier to rehabilitate than something the size of Rosewood or Southbury. Still, it does not seem unreasonable to ask for some measure of progress within this time period.

100. As an alternative to government-initiated action, GRIPA could expressly provide for attorney's fees to intervenors who brought suit against the state for failure to meet the statutory requirements of the Act. Such a proposal would effectively extend the scope of the Civil Rights Attorney's Fees Awards Act of 1976, 42 U.S.C. $\$ 1988$ (1982), which already provides for fee awards to private parties who successfully bring suit under 42 U.S.C. $\S 1983$ (1982). See, e.g., Horowitz, supra note 89, at 1279 (noting that in New York State Ass'n for Retarded Children v. Carey, plaintiffs' counsel received fee award of $\$ 613,992$ ). 
all deficiencies within this second period; ${ }^{101}$ it merely mandates that the state make some progress in this direction such that the Justice Department can be assured that suit need not be filed to compel action. ${ }^{102}$

\section{B. Ensuring Adequate Representation}

The state and the federal government could negotiate a decree, as in Southbury, which fails to vindicate the rights of the plaintiff class. ${ }^{103}$ CRIPA, therefore, must be amended to ensure that before a decree is entered, the court has had the opportunity to hear the full range of perspectives on the proposed decree. This goal could be accomplished by inserting a provision requiring that before a decree is entered by the court, there be fairness hearings ${ }^{104}$ where plaintiff-intervenors and amici curiae can present their claims and dispute any part of the decree which they find unacceptable. ${ }^{105}$ At the conclusion of the hearings, the judge may accept the original decree or request that it be modified in accordance with suggestions and concerns she has heard. In the latter case, she would order the

101. Such a requirement would be untenable since state legislatures would be unlikely to authorize necessary increases in funding until they were judicially bound to do so by a consent decree. It is possible, however, for state governments to redress structural problems not tied to funding shortages, such as inadequate recordkeeping and poor delivery of medical services, and these problems constitute a majority of those in need of redress. Telephone interview with Robin Frohboese, Staff Attorney, Special Litigation Division, Department of Justice (Oct. 1987).

102. The argument that this proposal would lead to an explosion of litigation, and thus drain the Justice Department's resources, assumes erroneously that filing suit is synonymous with going to trial. Faced with the specter of full-scale litigation, states are likely to increase efforts to negotiate a settlement, realizing that the Justice Department would not bring charges in the first place without conclusive evidence of CRIPA violations. The state, moreover, will be notified of the breadth of the government's evidence in the "49-day letter." Thus, going to trial makes sense only if the state feels it can successfully challenge the adequacy of this evidence. This result is sufficiently unlikely to dispel concerns about the expense of implementing the six-month provision.

103. See supra text accompanying notes 56-68.

104. This proposal would effectively extend FED. R. Giv. P. 23(e) governing judicial approval of class action suits to suits brought by the Justice Department under CRIPA. Accordingly, the judge would use the hearings to ensure that the decree was fair, reasonable, and adequate before she signed it into law. For a similar proposal in the school desegregation context, see Note, Participation and Department of Justice School Desegregation Decrees, 95 YALE L.J. 1811, 1829-34 (1986).

105. Opponents of such hearings would emphasize their cost and the resultant delay in the resolution of the case. As for cost, while it is true that the court would be required to hear testimony on a decree it may consider acceptable as originally drafted, the hearings might uncover problems that have gone unnoticed. If hearings had been held on the Southbury decree, for example, the district judge might have rejected its treatment of community placement and insisted on more substantial monitoring, in light of concerns raised by proposed intervenors' testimony.

As for problem of delay, it is true that the decree could not be entered by the court until the hearings were concluded, but the potential delay caused by the present procedure is even greater. Motions to intervene may currently be filed only after a proposed decree is submitted to the court, thus delaying the resolution of the case. In Southbury, for example, the decree was submitted by the litigating parties in July 1986, at which time three motions were filed. The court did not dismiss the motions until some five months later, before which time it could not enter the decree. The proposed amendment would not allow for such delays. To satisfy the "timeliness" requirement, motions to intervene would need to be filed while negotiations were in progress, not after their conclusion. See NAACP v. New York, 413 U.S. 345, 365 (1973) (timeliness is first requirement movant must meet to intervene successfully); Note, The Timeliness Threat to Intervention of Right, 89 Y ALE L.J. 586, 593 (1980) (same); see also Deveraux v. Geary, 765 F.2d 268, 270 (1st Gir. 1985) (timeliness assessed in part by length of time intervenors knew or should have known of their interest before petitioning). 
litigating parties, i.e. the state and federal governments, to recast the document; ${ }^{108}$ if they failed to do so in accordance with her instructions, she could reformulate the unacceptable parts of the decree herself and prevent any further governmental participation in the process.

The benefits to be gained from intervention will be lost if judges deny legitimate motions to intervene. CRIPA should thus be amended to afford a statutory right of intervention to any agency or organization which meets the requirements of Rule 24(a)(2) of the Federal Rules of Civil Procedure, minus the language about the adequacy of representation by existing parties. ${ }^{107}$ There is ample evidence of the danger of allowing one party to represent the interests of a group as vulnerable as the retarded, and of the particular failures of the federal government in this regard. ${ }^{108}$ Thus, it is important to fashion CRIPA so as to allow those with demonstrated interests to be heard, while not unduly delaying the adjudicatory process. This proposal satisfies both requirements. ${ }^{109}$

\section{G. Monitoring the Settlement}

The Act should also be amended to include an independent monitoring body, ${ }^{110}$ since the Justice Department's physical absence from the institution makes it unable to carry out its monitoring responsibilities effectively. ${ }^{111}$ Various schemes used in prior institutional litigation have met with varying degrees of success; ${ }^{112}$ the monitoring proposal put in place

106. To allow all parties of interest to participate in this remedial phase would unduly delay the process of negotiation and is unnecessary since the litigating parties would be constrained to reform the decree within the parameters specified by the judge.

107. Thus, the intervenor must "claim an interest relating to the property or transaction which is the subject of the action" and be "so situated that the disposition of the action may as a practical matter impair or impede his ability to protect that interest." Liberalizing intervention in this manner will allow diverse viewpoints to be voiced. See Jones, Litigation Without Representation: The Need for Intervention to Affirm Affirmative Action, 14 HARv. C.R.-C.L. L. REv. 31 (1979); Weinstein, Litigation Seeking Changes in Public Behavior and Institutions-Some Views on Participation, 13 U.C. Davis L. REv. 231, 241 (1980).

108. See, e.g., supra text accompanying notes 56-67.

109. Allowing such broad participation would not unduly delay adjudication since the time period for conducting hearings would be statutorily limited, and intervenors would be excluded from the actual negotiation of the decrees.

110. As one expert in the field noted, "nothing happens without monitoring." Interview with Michael Lottman, Executive Director of the Mansfield Review Panel (CARC v. Thorne) (Nov. 1987).

111. See supra text accompanying note 68 .

112. Wyatt v. Stickney established a "Human Rights Committee" of seven non-experts in mental retardation to supervise the decree concerning Partlow State Hospital. 344 F. Supp. 387, 394, 407 (M.D. Ala. 1972). The committee was not, however, very effective; its members worked part-time only, lacked the resources and expertise to monitor the institution effectively, and were not given the authority to translate transgressions into punishment. See Lottman, Enforcement of Judicial Decrees: Now Comes the Hard Part, 1 Mental Disability L. Rep. 69, 71-72 (1976).

Knowledge of the difficulties at Partlow informed the creation of a "review panel" at Willowbrook. See generally id. at 72-74. The seven-member staff was assigned three full-time assistants and was granted access to all facilities and files necessary to judge compliance. Id. at 72-73 (citing New York State Ass'n for Retarded Children and Parisi v. Carey, No. 72-C-356/357 (E.D.N.Y. Apr. 30, 1975)). The panel was also given the power to enforce recommendations when made pursuant to the 
under GRIPA should draw on these experiences. It should ensure, for example, that monitors have access to all buildings and files necessary to judge compliance. Monitors should also be full-time employees, paid by the federal government, so that they are available to inspect conditions at the institution on a day-to-day basis and visit community placements, where necessary. ${ }^{113}$

It is impractical to choose monitors who have had no experience with the mentally retarded. Their lack of expertise would necessitate the hiring of an additional staff of consultants which would both escalate the overall cost of monitoring and complicate its execution. ${ }^{114}$ In addition to having experience in the retardation field, monitors should be chosen, where possible, who have a demonstrated personal interest in the decree. Fortunately, the court has ready access to such individuals in the form of plaintiff-intervenors who have presumably participated in hearings on the proposed decree. Each intervenor, and the litigating parties, should be allowed one representative on the monitoring panel. ${ }^{115}$ This procedure would guarantee that those assigned monitoring duties would have extensive experience with the consent decree and the institution benefitted by it, as well as a history of advocacy for or service ${ }^{116}$ to the retarded. ${ }^{117}$

The monitoring body would report any evidence of noncompliance to a Special Master ${ }^{118}$ invested with the authority to compel the state to modify its behavior when he was sufficiently convinced that it was violating the decree. ${ }^{110}$ In making such a determination, the Master would allow

fulfillment of provisions in the decree. Id. at 73.

While an improvement, the Willowbrook panel had problems. The state often objected to its recommendations and the subsequent judicial review was usually protracted. The attendant lack of progress caused parents and advocacy groups to become increasingly frustrated and disillusioned with the panel. See id.

113. Hiring full-time monitors would increase the cost of monitoring, but such expense would not be borne indefinitely; the decrees typically expire after two years at which time monitoring ceases. The temporary cost is essential, moreover, to the effective implementation of decrees. The value of a remedy diminishes substantially in the absence of a mechanism to safeguard its provisions.

114. Maintaining two separate bodies, one with the expertise and the other with authority, would be an inefficient and illogical division of responsibility.

115. There should be flexibility, however, in the size of the monitoring body given the variation in the size of institutions. Where the number of monitors, calculated as specified in this proposal, is, in the judgment of the court, inadequate to meet the needs of the situation, the court should appoint additional monitors or, if it prefers, assign responsibility for appointing additional monitors equally to the litigating parties. There is no danger in allowing the Justice Department to participate in monitoring in this way since other parties will be present to dilute any bias it might introduce.

116. Such interest has been demonstrated by unions, as when District 1199 intervened in CARC v. Thorne, No. H-78-653 (D. Conn. Nov. 7, 1983).

117. Given the diversity of perspectives on the panel, unanimous support for any given decree provision is likely to be a rare occurrence. This, however, should not hinder enforcement, for there will always be some monitors sufficiently in favor of a provision to ensure compliance.

118. The court in IVyatt $v$. Stickney reserved the power to appoint a master but never did so. 344 F. Supp. 373, 376-77 (M.D. Ala. 1972); 344 F. Supp. 387, 392-93 (M.D. Ala. 1972); see Lottman, supra note 112 , at 71 .

119. The court may invest the master with such power under FED. R. Grv. P. 53(c): "The order of reference [from the judge] to the master may specify or limit his powers. . . . Subject to the specifications and limitations stated in the order, the master has and shall exercise the power to regulate all 
both the state and the panel to present evidence of compliance with the decree, or lack thereof, in a formal hearing. At the conclusion of the proceeding, he would render a decision and file it with the clerk of the court, in fulfillment of Rule 53(e) of the Federal Rules of Civil Procedure. ${ }^{120}$ If the state objected to the Master's holding, it would be free to appeal the ruling in federal district court. ${ }^{121}$

\section{Gonclusron}

The need for reform of institutions for retarded citizens is as great today as it was in 1980 when Congress enacted CRIPA. The federal government not only has a role to play in this process, it has a responsibility to defend those citizens who are unable to seek redress of constitutional rights denied them. The government's performance over the past seven years has been far from exemplary in this regard. Legislative changes are necessary to augment the Justice Department's efforts and accomplish at last the goals of the Civil Rights of Institutionalized Persons Act.

proceedings in every hearing before him and to do all acts and take all measures necessary or proper for the efficient performance of his duties under the order." For a discussion of the use of special masters in the institutional reform context, see Burt, Pennhurst: A Parable, in IN THE INTEREST of ChILdREN 345 (R. Mnookin ed. 1985) (appointment of special master is "an extraordinary and rarely exercised judicial power"). But see Horowitz, supra note 89, at 1275-76, 1300 (increased delegation of judicial responsibility to special masters in 1980's). See generally Fiss, supra note 90, at 56-57; Kirp \& Babcock, Judge and Company: Court-Appointed Masters, School Desegregation, and Institutional Reform, 32 ALA. L. REv. 313 (1981); Starr, Accommodation and Accountability: A Strategy for Judicial Enforcement of Institutional Reform Decrees, 32 ALA. L. REv. 399, 407-12 (1981).

120. Rule 53(e)(1) provides: "The master shall prepare a report upon the matters submitted to him by the order of reference and, if required to make findings of fact and conclusions of law, he shall set them forth in the report. He shall then file the report with the clerk of the court . . .."

121. Special masters are hardly novel in institutional reform litigation, but their main application to date has been in the prison context. See, e.g., Hamilton v. Schiro, 338 F. Supp. 1016 (E.D. La. 1970), 1 Prison L. RPTR. 185 (May 1972); Hamilion v. Landrieu, 351 F. Supp. 549 (E.D. La. 1972). See generally Hart v. Community School Bd., 333 F. Supp. 699 (E.D.N.Y. 1974); Smithson, The Special Master in Correctional Cases: A Preliminary Survey, 9 Chearinghouse Rev. 15 (1975).

The one notable use of a special master in the context of institutions for retarded people came in Halderman v. Pennhurst State School \& Hosp., 446 F. Supp. 1295 (E.D. Pa. 1977). The Pennhurst Master, however, was not invested with powers nearly as broad as those advocated here. Her Office had basically three responsibilities: to formulate compliance plans and timetables, to plan the training of personnel to carry out those plans, and to monitor the defendants' adherence to those plans. Id. at 1326-27. The Master thus did not have the authority to issue remedial orders; in fact, she did not even accept the power granted to her by the court to initiate compliance plans, feeling that the defendants were better able to do so than she since they were better aware of their resources and capabilities. She felt that her job was merely to review the plan they had formulated. Burt, supra note 119, at 346. 